\title{
Four Cases of X-Linked Hypophosphatemic Rickets, Clinical Description and Genetic Testing
}

\author{
David Vila-Pérez ${ }^{*}$, Sílvia Marín-del-Barrio² ${ }^{2}$ Jordi Vila-Cots', \\ Jose Antonio Camacho-Díaz ${ }^{1}$, Marcos Morey ${ }^{3}$, Lourdes Loidi ${ }^{3}$ \\ ${ }^{1}$ Department of Nephrology, Hospital Sant Joan de Déu, Barcelona, Spain \\ ${ }^{2}$ Department of Endocrinology, Hospital Sant Joan de Déu, Barcelona, Spain \\ ${ }^{3}$ Department of Genomics, Fundación Pública Galega de Medicina Xenómica, Santiago de Compostela, Spain \\ Email: ${ }^{*}$ dvila@hsjdbcn.org
}

Received 12 January 2014; revised 10 February 2014; accepted 8 March 2014

Copyright (C) 2014 by authors and Scientific Research Publishing Inc.

This work is licensed under the Creative Commons Attribution International License (CC BY). http://creativecommons.org/licenses/by/4.0/

(c) (i) Open Access

\begin{abstract}
One of the major causes of congenital hypophosphatemic rickets is the $\mathrm{X}$-linked hypophosphatemic rickets (XHR), due to a defect on PHEX gene. The XHR increases the renal elimination of phosphate, that condition leads a defective mineralization of bones and also affects the growth in children. Clinical diagnosis should be suspected in children with signs of rickets and hypophosphatemia with normal calcium levels. We describe clinical characteristics and genetic results of four patients diagnosed and treated in our Nephrology Section. All patients have a "de novo" XHR as none familiars are affected. Early diagnosis should be suspected before the bone deformities have been submitted and the growth would have been impaired.
\end{abstract}

\section{Keywords}

Rickets; X-Linked Hypophosphatemic Rickets; XHR; PHEX Gene

\section{Introduction}

X-linked hypophosphatemic rickets (XHR, OMIM 307800) is a dominant inherited disorder characterized by renal phosphate wasting, leading to chronic hyperphosphaturia and hypophosphatemia, which are associated to unsuitable normal or low levels of $1.25(\mathrm{OH})_{2}$ Vitamin $\mathrm{D}_{3}$. This phosphorus-wasting disturbance affects bone metabolism, yielding rickets in pediatric patients and osteomalacia in adults [1]-[4].

${ }^{*}$ Corresponding author. 
Parathyroid hormone (PTH) and Fibroblast Growth Factor 23 (FGF-23) act as phosphaturic agents, reducing phosphorus reabsorption in the proximal tubules, through NaPiT-II co-transporters inhibition. In XHR, hyperphosphaturia derives from mutations in the PHEX gene (Phosphate regulating gene with homologies to Endopeptidases on the X-chromossome) $(1$ - 3, 13 - 16). This gene, whose locus is Xp22.1, encodes a membrane endopeptidase, called PHEX, mainly expressed in bone and teeth [1]-[7].

The mutations in PHEX gene associated to XRH yield a decrease or absence of action of PHEX, thus increasing FGF-23 actions in the inactivation of NaPiT-II co-transporters, leading to a decreased phosphorus tubular reabsorption [1]-[7]. In XRH, dentin mineralization is impaired, with the defect appearing as unmerged, persistent mineralization foci surrounded by extensive interglobular regions of unmineralized dentin matrix [8]. These abnormalities may lead to rapid pulp necrosis associated with periapical bone infection.

\section{Subjects and Methods}

The patients described here were diagnosed with XHR in our center and are visited regularly in the Nephrology and Endocrinology Services. Diagnosis of XHR was based on clinical and radiological findings of rickets, skeletal deformities, and growth impairment as well as laboratory data indicating hypophosphatemia.

We reviewed the medical records from the patients and data of clinical aspects and laboratory testing was collected. In all genetic study has been undertaken after diagnosis and once initiated treatment. We used peripheral blood samples for genetic testing that were refered to a external laboratory, where techniques as real time polymerase chain reaction and multiplex ligation dependent probe amplification assay were performed.

Informed consent was obtained from the patients or their parents. The authors declare no conflict of interest.

\section{Results}

There were 4 patients followed in our service, half of them males. All of them were referred by their pediatrician to our center with suspect of rickets, mainly by tibia vara and short height. Diagnostic was made between 2 and 4 years of life. All of them presented with clinical and radiological signs of rickets at diagnosis and with hypophosphatemia and normocalcemia. In Table 1, there are summarized some clinical and laboratory findings at diagnosis.

All the patients had grown impairment (with height percentiles between P1 and P19 according to age). During the follow up data growth data was recorded and summarized in Table 2.

The treatment undertaken was phosphate and calcitriol. The phosphate was in form of Solution of Joulie at doses between 60 and $100 \mathrm{mg} / \mathrm{kg} /$ day of phosphate. The dose of calcitriol was 0 ' $25 \mathrm{mcg}$ twice a day in all patients.

Three of the patients referred a transient secondary hyperparathyroidism, with levels of parathyrine between 16 ' 8 and 33'3 pmol/L (normal values 0.5 - $5.5 \mathrm{pmol} / \mathrm{L}$ ).

The genetic tests performed showed different mutations. The patient 1 did not present any punctual mutation of PHEX gene. A multiplex ligation dependent probe amplification assay was performed and it suggested a deletion of exon 3 of PHEX. The patient 2 had the mutation NM_000444.4:c.565C > T (p.Gln549X) in exon 5 of PHEX that encoded a premature stop codon. In patient 3, there was found the mutation NM_000444.4:c.591A > G (c.591A > G) in exon 5 of PHEX, that encoded a change of the nucleotide, an adenine instead of a guanine, in the third position of codon number 197. The patient 4 was found to have the mutation NM_000444.4:c.1645C >

Table 1. Clinical and genetical description of patients.

\begin{tabular}{|c|c|c|c|c|}
\hline & Patient 1 & Patient 2 & Patient 3 & Patient 4 \\
\hline Gender & Female & Male & Male & Female \\
\hline Age at diagnosis (months) & 34 & 24 & 41 & 50 \\
\hline Rickets signs & Tibia vara growth retardation & Tibia vara ankle deformation & Tibia vara & Tibia vara \\
\hline Calcium ionic at diagnosis $(\mathrm{mmol} / \mathrm{L})$ & $2 ’ 42$ & $2 ’ 48$ & $2 ’ 35$ & $2 ’ 54$ \\
\hline Phosphate at diagnosis $(\mathrm{mmol} / \mathrm{L})$ & $0 ’ 84$ & $0 ’ 99$ & $0 ’ 95$ & $0{ }^{\prime} 80$ \\
\hline Alcaline phosphatase at diagnosis (U/L) & 558 & 738 & 449 & 448 \\
\hline
\end{tabular}


Table 2. Height characteristics of patients.

\begin{tabular}{ccccc}
\hline & Patient 1 & Patient 2 & Patient 3 & Patient 4 \\
\hline Gender & Female & Male & Male & Female \\
Age at diagnosis (months) & 34 & 24 & 91 & 96 \\
Height at diagnosis (cm) & 86 & 81 & 96 & P2 (-2.1) \\
Height percentile at diagnosis (SD) & P2 (-2.3) & P $<1(-2.4)$ & P19 (-0.9) & 16 \\
Age at end of follow up (years) & 15 & 5 & 114 & P2 (-2.1) \\
Height at end of follow up & 149 & $\mathrm{P}<1(-2.35)$ & $\mathrm{P}<1(-2.6)$ & P
\end{tabular}

T (p.Arg549X) in exon 15 of PHEX gene that encoded a premature stop codon. There were no familiars affected and none of the mothers had the same mutation as any of the patients.

\section{Discussion}

Rickets is a disease characterized by defective mineralization of osteoid matrix during growth, leading to the development of bone defects and the presence of short stature. One of the causes of rickets is hypophosphatemia, which is usually presented without the characteristic signs of hypocalcemic rickets such as involvement of ribs and upper limbs. The main causes of hypophosphatemic rickets in the developed world are the familiar rickets, and one of the most frequent is familial X-linked hypophosphatemic rickets (XHR) [9]-[12].

The XHR is characterized by an increased renal elimination of phosphate which leads to a hypophosphatemia with normal calcium levels. The causative mechanism is an alteration in the regulatory mechanisms of major renal phosphate transporter, the transporter NaPiT-II. In the XHR, the FGF-23 levels, whose functions are the inhibition of the transporter NaPiT-II and to inhibit the activity of the $25(\mathrm{OH})-1$-hydroxylase impairment, are increased and leads to a raise in phosphaturia [1] [13]-[16].

This increase in FGF-23 is produced by a deficit of PHEX protein, a transmembrane protein that promotes FGF-23 cleavage in smaller and two inactive peptides, encoded by the gene PHEX, located on chromosome Xp22.1 [1]-[7] [17].

The diagnosis of XHR is based on a consistent medical history and physical examination, radiological evidence of rachitic disease, compatible laboratory values and a family history consistent with XHR or the demonstration of PHEX mutations [18].

In our study, all our patients had predominantly lower limb abnormalities, short stature and compatible laboratory testing, summarized in Table 1, showing a low phosphate with normal calcemia. Alkaline phosphatase is useful at the time of diagnosis to monitor the treatment side.

The genetic testing is usually performed as a confirmatory test in addition to ensure proper genetic counseling. Patients 2 and 4 had two mutations already described in the literature, leading to the presence of a premature stop codon and thus an abnormal protein [19] [20].

In the first patient, we did not detect any mutation in the gene sequencing, which is why a study by MLPA was undertaken, which showed a lack of the exon 3 of PHEX gene. The MLPA technique can detect the presence of deletions in the gene PHEX effectively as they have been shown in some studies [21].

In the case of patient 3 , presenting the mutation (c.591A > G) corresponds to exon 5 of the PHEX gene. This mutation causes a change in the nucleotide (an adenine by a guanine) in the third position of codon 197. Theoretically, this change would not cause any amino acid change, however were made theoretical predictions of mRNA by "Splice Site Finder-like", "Max Ent Scan" and "NNSPLICE" that pointed to the emergence of an abnormal splicing site resulting in a shorter exon and therefore to an abnormal protein. This mutation has recently been described [21].

All our 4 patients sterted a Joulie solution treatment as a method of administration of phosphate with the administration of calcitriol. Secondary, hyperparatyroidism is a freqüent complication of this threatment due to direct paratyroid stimulation by inorganic phosphate (Pi); others may develop even a tertiary hyperparatyroidism. That condition increases phosphaturia despite hypophosphatemia. In our case, we lowered the dose of Pi; but 
there has been reported the use of calcimimetics with apparently good results [22]-[24].

Despite adequate treatment, the growth at follow-up remained below 2 standard deviations of the normal range for their age. According the published data, the cumulative growth deficit prior to diagnosis is the main cause of a low final height [25]-[27].

Growth hormone increases glomerular filtration rate and effective renal plasma flow, and it has been found to increase the renal phosphate reabsortion in animal models [28], moreover growth hormone treatment stimulates bone remodeling [29]-[31]. For these reasons there have been several studies with recombinant human growth hormone (rhGH) in children suffering from XHR to prevent a final stature at the end of puberty.

According to these studies appears to be an improvement in final height [32] [33] altough it may aggravate pre-existing skeletal deformities [34], but the low number of cases and the lack of randomized studies do not allow recommendations.

In conclusion, although the diagnosis is mainly clinical, molecular genetic tests can help make an early diagnosis, before the bone deformities have been submitted and the growth would have been impaired.

\section{Acknowledgements}

We would like to thank Dr. L. Loidi and her team from Fundación Pública Galega de Medicina Xenómica for their support in genetic testing.

\section{References}

[1] Quarles, L.D. (2003) Evidence for a Bone-Kidney Axis Regulating Phosphate Homeostasis. Journal of Clinical Investigation, 112, 642-646. http://dx.doi.org/10.1172/JCI200319687

[2] Rowe, O.S. (2000) The molecular background to hypophosphatemic rickets. Archives of Disease in Childhood, 83, 192-194. http://dx.doi.org/10.1136/adc.83.3.192

[3] Cho, H.Y., Lee, B.J., Kang, J.H., Ha, I.S., Cheong, H.I. and Choi, Y. (2005) A clinical and molecular genetic study of hypophosphatemic rickets in children. Pediatric Research, 58, 329-333. http://dx.doi.org/10.1203/01.PDR.0000169983.40758.7B

[4] Bielesz, B., Klaushofer, K. and Oberbauer, R. (2004) Renal Phosphate Loss in Hereditary and Acquired Disorders of Bone Mineralization. Bone, 35, 1229-1239. http://dx.doi.org/10.1016/j.bone.2004.08.009

[5] Rowe, P. (2004) The Wrickkened Pathways of FGF-23, MEPE and PHEX. Critical Reviews in Oral Biology \& Medicine, 15, 264-281. http://dx.doi.org/10.1177/154411130401500503

[6] de Beur, S.M.J. and Levine, M.A. (2002) Molecular Pathogenesis of Hypophosphatemic Rickets. The Journal of Clinical Endocrinology \& Metabolism, 87, 2467-2473. http://dx.doi.org/10.1210/jcem.87.6.8688

[7] Saggese, G. and Baroncelli, G.I. (2000) Hypophosphatemic Rickets. Hormone Research in Paediatrics, 53, 57-60. http://dx.doi.org/10.1159/000023535

[8] Chaussain-Miller, C., Sinding, C., Septier, D., Wolikow, M., Goldberg, M., et al. (2007) Dentin Structure in Familial Hypophosphatemic Rickets: Benefits of Vitamin D and Phosphate Treatment. Oral Diseases, 13, 482-489. http://dx.doi.org/10.1111/j.1601-0825.2006.01326.x

[9] Wharton, B. and Bishop, N. (2003) Rickets. Lancet, 362, 1389-1400. http://dx.doi.org/10.1016/S0140-6736(03)14636-3

[10] Root, A.W. and Diamond Jr., F.B. (2002) Disorders of Calcium Metabolism in the Child and Adolescent. In: Sperling M.A., Ed., Pediatric Endocrinology, 2nd Edition, Saunders, Philadelphia, 646.

[11] Garg, R.K. and Tandon, N. (1999) Hypophosphatemic Rickets: Easy to Diagnose, Difficult to Treat. Indian Journal of Pediatrics, 66, 849-857. http://dx.doi.org/10.1007/BF02723852

[12] Winters, R., Grahan, J., Williams, T., McFalls, V. and Burnett, C. (1958) A Genetic Study of Familial Hypophosphatemia and Vitamin D Resistant Rickets with a Review of the Literature. Medicine, 37, 97-142. http://dx.doi.org/10.1097/00005792-195805000-00001

[13] Segawa, H., Kaneko, I., Takahashi, A., Kuwahata, M., Ito, M., Ohkido, I., et al. (2002) Growth-Related Renal Type II $\mathrm{Na} / \mathrm{Pi}$ Cotransporter. The Journal of Biological Chemistry, 277, 19665-19672. http://dx.doi.org/10.1074/jbc.M200943200

[14] Murer, H., Forster, I. and Biber, J. (2004) The Sodium Phosphate Cotransporter Family SLC34. Pflugers Arch, 447, 763-767. http://dx.doi.org/10.1007/s00424-003-1072-5

[15] Strewler, G.J. (2001) FGF23, Hypophosphatemia, and Rickets: Has Phosphatonin Been Found? Proceedings of the 
National Academy of Sciences of the United States of America, 98, 5945-5946. http://dx.doi.org/10.1073/pnas.111154898

[16] Riminucci, M., Collins, M.T., Fedarko, N.S., Cherman, N., Corsi, A., White, K.E., et al. (2003) FGF-23 in Fibrous Dysplasia of Bone and Its Relationship to Renal Phosphate Wasting. The Journal of Clinical Investigation, 112, 683-692. http://dx.doi.org/10.1172/JCI18399

[17] Bowe, A.E., Finnegan, R., de Beur, S.M.J., Cho, J., Levine, M.A., Kumar, R., et al. (2001) FGF-23 Inhibits Renal Tubular Phosphate Transport and Is a PHEX Substrate. Biochemical and Biophysical Research Communications, 284, 977-981. http://dx.doi.org/10.1006/bbrc.2001.5084

[18] Dixon, P.H., Christie, P.T., Wooding, C., Trump, D., Grieff, M., Holm, I., et al. (1998) Mutational Analysis of PHEX Gene in X-Linked Hypophosphatemia. The Journal of Clinical Endocrinology \& Metabolism, 83, 3615-3623.

[19] Yamazaki, Y., Okazaki, R., Shibata, M., Hasegawa, Y., Satoh, K., Tajima, T., Takeuchi, Y., Fujita, T., Nakahara, K., Yamashita, T. and Fukumoto, S. (2002) Increased Circulatory Level of Biologically Active Full-Length FGF-23 in Patients with Hypophosphatemic Rickets/Osteomalacia. The Journal of Clinical Endocrinology \& Metabolism, 87, 4957-4960. http://dx.doi.org/10.1210/jc.2002-021105

[20] Rowe, P.S., Oudet, C.L., Francis, F., Sinding, C., Pannetier, S., Econs, M.J., Strom, T.M., Meitinger, T., Garabedian, M., David, A., Macher, M.A., Questiaux, E., Popowska, E., Pronicka, E., Read, A.P., Mokrzycki, A., Glorieux, F.H., Drezner, M.K., Hanauer, A., Lehrach, H., Goulding, J.N. and O’Riordan, J.L. (1997) Distribution of Mutations in the PEX Gene in Families with X-Linked Hypophosphataemic Rickets (HYP). Human Molecular Genetics, 6, 539-549. http://dx.doi.org/10.1093/hmg/6.4.539

[21] Morey, M., Castro-Feijoo, L., Barreiro, J., Cabanas, P., Pombo, M., Gil, M., et al. (2011) Genetic Diagnosis of X-Linked Dominant Hypophosphstemic Rickets in a Cohort Study: Tubular Reabsorption of Phosphate and 1,25 (OH) 2D Serum Levels Are Asociated with PHEX Mutation Type. BMC Medical Genetics, 12, 116. http://dx.doi.org/10.1186/1471-2350-12-116

[22] Alon, U.S., Levy-Olomucki, R., Moore, W.V., Stubbs, J., Liu, S. and Quarles, L.D. (2008) Calcimimetics as an Adjuvant Treatment for Familial Hypophosphatemic Rickets. Clinical Journal of the American Society of Nephrology, 3, 658-664. http://dx.doi.org/10.2215/CJN.04981107

[23] Yavropoulou, M.P., Kotsa, K., Gotzamani Psarrakou, A., Papazisi, A., Tranga, T., Ventis, S. and Yovos, J.G. (2010) Cinacalcet in Hyperparathyroidism Secondary to X-Linked Hypophosphatemic Rickets: Case Report and Brief Literature Review. Hormones (Athens), 9, 274-278. http://dx.doi.org/10.14310/horm.2002.1277

[24] Raeder, H., Shaw, N., Netelenbos, C. and Bjerknes, R. (2008) A Case of X-Linked Hypophosphatemic Rickets: Complications and the Therapeutic Use of Cinacalcet. European Journal of Endocrinology, S101-S105. http://dx.doi.org/10.1530/EJE-08-0383

[25] Mäkitie, O., Doria, A., Kooh, S.W., Cole, W.G., Daneman, A. and Sochett, E. (2003) Early Treatment Improves Growth and Biochemical and Radiographic Outcome in X-Linked Hypophosphatemic Rickets. The Journal of Clinical Endocrinology \& Metabolism, 88, 3591-3597. http://dx.doi.org/10.1210/jc.2003-030036

[26] Pereira, C.M., Andrade, C.R., Vargas, P.A., Coletta, R.D., Almeida, O.P. and Lopes, M.A. (2004) Dental Alterations Associated with X-Linked Hypophosphatemic Rickets. Journal of Endodontics, 30, 241-245. http://dx.doi.org/10.1097/00004770-200404000-00015

[27] Chaussain-Miller, C., Sinding, C., Wolikow, M., Lasfargues, J.J., Godeau, G. and Garabédian, M. (2003) Dental Abnormalities in Patients with Familial Hypophosphatemic Vitamin D-Resistant Rickets: Prevention by Early Treatment with 1-Hydroxyvitamin D. The Journal of Pediatrics, 142, 324-331.http://dx.doi.org/10.1067/mpd.2003.119

[28] Haramati, A., Mulroney, S.E. and Lumpkin, M.D. (1990) Regulation of Renal Phosphate Reabsorption during Development: Implications from a New Model of Growth Hormone Deficiency. Pediatric Nephrology, 4, 387-391. http://dx.doi.org/10.1007/BF00862524

[29] Brixen, K., Nielsen, H.K., Mosekilde, L. and Flyvbjerg, A. (1990) A Short Course of Recombinant Human Growth Hormone Treatment Stimulates Osteoblasts and Activates Bone Remodeling in Normal Human Volunteers. Journal of Bone and Mineral Research, 5, 609-618. http://dx.doi.org/10.1002/jbmr.5650050610

[30] Brixen, K., Nielsen, H.K., Bouillon, R., Flyvbjerg, A. and Mosekilde, L. (1992) Effects of Short-Term Growth Hormone Treatment on PTH, Calcitriol, Thyroid Hormones, Insulin and Glucagon. Acta Endocrinology, 127, 331-336.

[31] Baroncelli, G.I., Bertelloni, S., Ceccarelli, C. and Saggese, G. (2001) Effect of Growth Hormone Treatment on Final Height, Phosphate Metabolism, and Bone Mineral Density in Children with X-Linked Hypophosphatemic Rickets. Journal of Pediatrics, 138, 236-243. http://dx.doi.org/10.1067/mpd.2001.108955

[32] Seikaly, M.G. and Baum, M. (1995) Stimulation of Growth Hormone Secretion in Children with x-Linked Hypophosphatemia. Pediatric Nephrology, 9, 751-752. http://dx.doi.org/10.1007/BF00868733

[33] Seikaly, M.G., Brown, R. and Baum, M. (1997) The Effect of Recombinant Human Growth Hormone in Children with 
X-Linked Hypophosphatemia. Pediatrics, 100, 879-884. http://dx.doi.org/10.1542/peds.100.5.879

[34] Makitie, O., Toiviainen-Salo, S., Marttinen, E., Kaitila, I., Sochett, E. and Sipila, I. (2008) Metabolic Control and Growth during Exclusive Growth Hormone Treatment in X-Linked Hypophosphatemic Rickets. Hormone Research in Paediatrics, 69, 212-220. http://dx.doi.org/10.1159/000113021

\section{Abbreviations}

XHR: X-Linked hypophosphatemic rickets

PTH: Parathyroid hormone

FGF-23: Fibroblast Growth Factor 23

PHEX: Phosphate regulating gene with homologies to endopeptidases on the X-chromosome SD: Standard deviation 